\title{
Deoxyribonucleic Acid Base Sequence Relatedness Among Strains of Pichia ohmeri That Produce Dimorphic Ascospores
}

\author{
GAYLE B. FUSON, C. W. PRICE, $†$ AND H. J. PHAFF \\ Department of Food Science and Technology, University of California, Davis, California 95616

\begin{abstract}
Strains of Pichia ohmeri that form either spherical or hat-shaped ascospores
\end{abstract} \\ comprise a well-defined assemblage, distinct in deoxyribonucleic acid base se- \\ quence and composition from other phenotypically similar yeasts. Thus, spore \\ morphology, usually a stable systematic character, is not invariably reliable as a \\ major taxonomic criterion among yeasts.
}

Ascospore shape is normally considered a cardinal taxonomic character among yeasts and in some instances is the sole criterion for the separation of species or even genera (4). Since the genetics of spore shape has not yet been established, however, it is possible that striking differences in morphology could depend on only one or a few genes. If this is the case, ascospore shape could prove a less reliable character than heretofore imagined. Consistent with this notion, spore shape in most yeasts appears constant and species specific, but the exceptions cannot be ignored. In both Endomycopsis lipolytica (11) and Pichia membranaefaciens (3, Kurtzman, personal communication), a single strain may produce distinctly different ascospores.

In Pichia ohmeri, Wickerham and Burton (10) observed an unusual case: crosses between different pairs of haploid strains produced either spheroidal or hat-shaped spores. These authors did not establish the fertility of the hybrid ascospores, however, and thus some question remained whether the various strains represent a single genospecies or whether the uncommon mating behavior reflects residual relatedness among divergent yeasts. We have, therefore, used deoxyribonucleic acid (DNA) sequence comparison to assess the overall genetic similarity among several $P$. ohmeri strains of complementary mating type as well as their kinship to other phenotypically similar Pichia species.

\section{MATERIALS AND METHODS}

Organisms. The yeasts used in this study are shown in Table 1.

DNA purification. Cultivation of cells and the extraction and purification of whole-cell yeast DNA have been described elsewhere (7).

Determination of base composition. The guanine + cytosine $(\mathrm{G}+\mathrm{C})$ content of yeast nuclear DNA

† Present address: Department of Bacteriology and Immunology, University of California, Berkeley, CA 94720. was calculated from the buoyant density in cesium chloride by using the equation of Schildkraut et al. (8), as previously described (7).

DNA reannealing reactions. Sequence complementarity was determined by renaturation in $280 \mathrm{mM}$ $\mathrm{PB}$ (an equimolar mixture of mono- and dibasic sodium phosphate, $\mathrm{pH} 6.8$ ) at $25^{\circ} \mathrm{C}$ below the $T_{m}$ of native homologous DNA, as described in detail earlier (7). Rapidly renaturing minor DNA species were removed from the ${ }^{32} \mathrm{P}$-labeled reference DNA before reassociation (7). After reannealing reactions, duplex molecules were separated from unreacted DNA with $140 \mathrm{mM} \mathrm{PB}$ at $60^{\circ} \mathrm{C}$ by the hydroxylapatite batch technique (1). A PB molarity of $90 \mathrm{mM}$ was used for thermal elution studies of duplex molecules $(5,7)$. The data are presented as percentage of actual binding to hydroxylapatite (experimentally determined) and as percentage of relative binding (normalized to the homologous reaction).

\section{RESULTS AND DISCUSSION}

The yeast strains used are listed in Table 1. Among the strains of $P$. ohmeri, 75-54 ( $\left.\mathrm{h}^{-}\right)$produces only round spores when crossed with strains of opposite mating type (e.g., $75-52, \mathrm{~h}^{+}$), whereas 75-53 $\left(\mathrm{h}^{-}\right)$produces exclusively hatshaped spores in crosses with 75-52 $\left(\mathrm{h}^{+}\right)(10)$. An exceptional case is strain NRRL Y-1260, which yields hat-shaped ascospores when mated with either 75-53 or 75-54. The type strain 75-74 was isolated as a diploid, but became an asporogenous haploid during laboratory cultivation. Its mating type with respect to the other strains was not determined. We also compared strains of several Pichia species that either have phenotypic resemblance to $P$. ohmeri (3) or are similar in DNA base composition (6).

Our base composition data (Table 2) show that all four strains of $P$. ohmeri, the type strain of $P$. guilliermondii, and the type strain of $P$. membranaefaciens are indistinguishable on this basis. $P$. pinus and $P$. fermentans are significantly different from $P$. ohmeri in base composition. The phenotypic properties of these two species also differ considerably from those of $P$. 
ohmeri, and the natural habitat of $P$. pinus is distinct from that of $P$. ohmeri (3). None of the other yeasts studied is likely to be closely related to $P$. ohmeri, since in our experience yeasts with

TABLE 1. Yeast strains employed

\begin{tabular}{|c|c|c|c|}
\hline \multirow{2}{*}{ Species name } & \multicolumn{3}{|c|}{ Strain designation $^{a}$} \\
\hline & UCD & CBS & NRRL \\
\hline $\begin{array}{l}\text { Pichia fermentans Lod- } \\
\text { der }\end{array}$ & $56-5^{b}$ & 187 & Y-1619 \\
\hline $\begin{array}{l}P . \text { guilliermondii Wick- } \\
\text { erham }\end{array}$ & $75-74^{b}$ & 2030 & Y-2076 \\
\hline $\begin{array}{l}P . \quad \text { membranaefaciens } \\
\text { Hansen }\end{array}$ & $57-22^{b}$ & 107 & Y-2026 \\
\hline \multirow{4}{*}{$\begin{array}{l}P \text {. ohmeri (Etchells et } \\
\text { Bell) Kreger-van Rij }\end{array}$} & $75-73^{b}$ & 5367 & Y-1932 \\
\hline & $75-52$ & 2037 & $Y-2078$ \\
\hline & $75-53$ & 568 & $Y-2079$ \\
\hline & $75-54$ & 2038 & $\mathrm{Y}-2080$ \\
\hline $\begin{array}{l}P . \text { pijperi van der Walt } \\
\text { et Tscheuschner }\end{array}$ & $61-19^{b}$ & 2887 & \\
\hline P. pinus (Holst) Phaff & $75-76^{b}$ & 744 & \\
\hline $\begin{array}{l}\text { P. rhodanensis (Rami- } \\
\text { rez et Boidin) Phaff }\end{array}$ & $56-7^{b}$ & 5518 & $Y-7854$ \\
\hline P. scolyti (Phaff et & $59-62^{b}$ & 4802 & \\
\hline $\begin{array}{l}\text { Yoneyama) Kreger- } \\
\text { van Rij }\end{array}$ & & & \\
\hline $\begin{array}{l}\text { P. strasburgensis (Ra- } \\
\text { mirez et Boidin) Phaff }\end{array}$ & $56-8^{b}$ & 2939 & $Y-2383$ \\
\hline $\begin{array}{l}\text { P. wickerhamii (van der } \\
\text { Walt) Kreger-van Rij }\end{array}$ & $60-23^{b}$ & 4107 & \\
\hline \multicolumn{4}{|c|}{$\begin{array}{l}{ }^{a} \text { Culture collection abbreviations: UCD, Depart- } \\
\text { ment of Food Science and Technology Culture Collec- } \\
\text { tion, University of California, Davis; CBS, Centraal } \\
\text { Bureau voor Schimmelcultures, Delft, Netherlands; } \\
\text { NRRL, Northern Regional Research Laboratory, Peo- } \\
\text { ria, Ill. } \\
{ }^{b} \text { Type strain. }\end{array}$} \\
\hline
\end{tabular}

DNA base compositions differing by more than 1 to $2 \mathrm{~mol} \% \mathrm{G}+\mathrm{C}$ (as determined from the buoyant density) do not have significant DNA complementarity (2, 7; Phaff, Presley, and Holzschu, unpublished data). DNA base sequence comparisons (Table 3) show that all four strains of $P$. ohmeri have high sequence relatedness and little in common with the other species tested. Thus, the $P$. ohmeri strains form a well-defined assemblage genetically distinct from all other phenetically similar yeasts.

TABLE 2. Base composition of nuclear DNA of 13 yeasts of the genus Pichia

\begin{tabular}{|c|c|c|}
\hline Species & $\begin{array}{c}\text { Strain } \\
\text { designa- } \\
\text { tion }^{a}\end{array}$ & $\mathrm{Mol} \% \mathrm{G}+\mathrm{C}^{b} \pm \mathrm{SL}$ \\
\hline Pichia scolyti $i^{c}$ & $59-62$ & $40.1 \pm 0.26$ \\
\hline P. strasburgensis ${ }^{c}$ & $56-8$ & $40.6 \pm 0.23$ \\
\hline P. pijperic ${ }^{c}$ & $61=19$ & $42.5 \pm 0.09$ \\
\hline P. pinus ${ }^{c}$ & $75-76$ & $433.0 \pm 0.06$ \\
\hline$P$. fermentans $^{c}$ & $56-5$ & $43.1 \pm 0.27$ \\
\hline P. membranaefaciens ${ }^{c}$ & $57-22$ & $\widetilde{4} 4.3 \pm 0.44$ \\
\hline P. ohmeric & $75-73$ & $44.3 \pm 0.19$ \\
\hline P. guilliermondii ${ }^{c}$ & $75-74$ & $44.4 \pm 0.10$ \\
\hline P. ohmeri & $75-54$ & $44.5 \pm 0.21$ \\
\hline P. ohmeri & $75-53$ & $44.6 \pm 0.47$ \\
\hline P. ohmeri & $75-52$ & $44.7 \pm 0.24$ \\
\hline P. wickerhamii ${ }^{c}$ & $60-23$ & $45.6 \pm 0.26$ \\
\hline P. rhodanensis ${ }^{c}$ & $56-7$ & $51.9 \pm 0.15$ \\
\hline
\end{tabular}

${ }^{a}$ University of California at Davis, Food Science and Technology Collection strain number.

${ }^{b}$ Calculated from the average of at least four buoyant density determinations. Braces enclose those base composition values which are not separable at the $95 \%$ confidence level (Student-Newman-Keuls a posteriori range test [9]). SD, Standard deviation.

c Type strain.

TABLE 3. Percent reannealing between ${ }^{32} P$-labeled DNA from $P$. ohmeri 75-52 and DNA from seven strains of yeasts ${ }^{a}$

\begin{tabular}{|c|c|c|c|c|}
\hline Organism or tissue & $\begin{array}{c}\text { Strain } \\
\text { designation }^{b}\end{array}$ & $\%$ Actual binding ${ }^{c}$ & \% Relative binding ${ }^{d}$ & $\Delta T_{m(e)}$ \\
\hline P. ohmeri & $75-52$ & $89.7 \pm 1.18$ & $(100)$ & \\
\hline P. ohmerif & $75-73$ & $89.6 \pm 0.18$ & 100.0 & 0.7 \\
\hline P. ohmeri & $75-53$ & $88.3 \pm 0.48$ & 98.4 & 0.6 \\
\hline P. ohmeri & $75-54$ & $88.0 \pm 0.60$ & 98.0 & 0.6 \\
\hline P. guilliermondit ${ }^{f}$ & $75-74$ & $10.6 \pm 1.21$ & 6.8 & $-g$ \\
\hline P. membranaefaciens & $57-22$ & $6.7 \pm 0.84$ & 2.2 & $-g$ \\
\hline P. wickerhamii ${ }^{f}$ & $60-23$ & $6.6 \pm 0.23$ & 2.1 & $-^{g}$ \\
\hline Calf thymus & & $7.2 \pm 0.89$ & 2.8 & $-g$ \\
\hline
\end{tabular}

${ }^{a}$ A $0.2-\mu \mathrm{g}$ amount of ${ }^{32} \mathrm{P}$-labeled DNA (ca. $75,000 \mathrm{cpm} / \mu \mathrm{g}$ ) and $200 \mu \mathrm{g}$ of unlabeled DNA in $0.5 \mathrm{ml}$ of $280 \mathrm{mM}$ $\mathrm{PB}$ at $65^{\circ} \mathrm{C}$.

${ }^{b}$ University of California at Davis, Food Science and Technology Collection strain number.

${ }^{c}$ Average of triplicate samples corrected for zero-time binding $=0.12 \pm 0.18 \%$.

${ }^{d}$ Corrected for self-renaturation of labeled DNA $=4.82 \pm 0.77 \%$.

e $T_{m(e)}$ is the thermal elution midpoint, the temperature at which $50 \%$ of the adsorbed DNA is eluted from the hydroxylapatite. $\Delta T_{m(e)}$ is the decrease in $T_{m(e)}$ between the heterologous reaction and the homologous ( $P$. ohmeri 75-52) reaction.

Type strain.

${ }^{k} \Delta T_{m(e)}$ is not meaningful because of the substantial contribution of self-reassociated, labeled DNA to the thermal elution profile of this heterologous reaction. 
Although matings between the four Pichia ohmeri strains produce spores of different shapes, our data demonstrate their close kinship. Furthermore, Kurtzman (personal communication) has recently found that a few fertile progeny are produced by crosses among these same strains. Thus, $P$. ohmeri constitutes a valid species on both molecular and biological grounds. Our results indicate that differences in spore morphology do not necessarily reflect differences in the entire genomes of yeasts and should not be used as the basis for species separation unless supported by other criteria.

\section{ACKNOWLEDGMENTS}

This research was supported by Public Health Service Research grant GM-16307-08 from the National Institute of General Medical Sciences.

We gratefully acknowledge the capable assistance of Nancy Krauter in the DNA isolation and of Mary Miranda for diagnostic testing. We thank C. P. Kurtzman for supplying several of the yeast strains and for helpful discussions.

\section{REPRINT REQUESTS}

Address reprint requests to: $\mathrm{H}$. J. Phaff, Department of Food Science and Technology, University of California, Davis, CA 95616.

\section{LTERATURE CITED}

1. Brenner, D. J., G. R. Fanning, A. Rake, and K. E. Johnson. 1969. A batch procedure for thermal elution of DNA from hydroxylapatite. Anal. Biochem. 28:445459 .
2. Fuson, G. B., C. W. Price, and H. J. Phaff. 1979. Deoxyribonucleic acid sequence relatedness among some members of the yeast genus Hansenula. Int. J. Syst. Bacteriol. 29:64-69.

3. Kreger-van Rij, N. J. W. 1970. Pichia Hansen, p. 455554. In J. Lodder (ed.), The yeasts-a taxonomic study. North-Holland Publishing Co., Amsterdam.

4. Lodder, J. 1970. General classification of the yeasts, p. 133. In J. Lodder (ed.), The yeasts-a taxonomic study. North-Holland Publishing Co., Amsterdam.

5. Martinson, H. G., and E. B. Wagenaar. 1977. Thermal elution chromatography of nucleic acids on hydroxylapatite. Biochim. Biophys. Acta 474:445-455.

6. Nakase, T., and K. Komagata. 1970. Significance of DNA base composition in the classification of the yeast genus Pichia. J. Gen. Appl. Microbiol. 16:511-521.

7. Price, C. W., G. B. Fuson, and H. J. Phaff. 1978. Genome comparison in yeast systematics: delimitation of species within the genera Schwanniomyces, Saccharomyces, Debaryomyces, and Pichia. Microbiol. Rev. 42:161-193.

8. Schildkraut, C. L., J. Marmur, and P. Doty. 1962. Determination of the base composition of deoxyribonucleic acid from its buoyant density in $\mathrm{CsCl}$. J. Mol. Biol. 4:430-433.

9. Sokal, R. R., and F. J. Rohlf. 1969. Biometry; the principles and practice of statistics in biological research. W. H. Freeman and Co., San Francisco.

10. Wickerham, L. J., and K. A. Burton. 1954. A clarification of the relationship of Candida guilliermondii to other yeasts by a study of their mating types. J. Bacteriol. 68:594-597.

11. Wickerham, L. J., C. P. Kurtzman, and A. I. Herman. 1969. Sexuality in Candida lipolytica, p. 81-92. In D. G. Ahearn (ed.), Recent trends in yeast research, vol. 1 . Spectrum Georgia State University, Atlanta. 